\title{
Profile of continuous use drugs prescribed in primary health care and presence in list of essential drugs
}

\author{
Paula Lorenzoni Nunes ${ }^{1 *}$ (D), Vanessa Adelina Casali Bandeira ${ }^{1}$ (D), Vanessa Boeira Flores ${ }^{2}$ (D) , Andressa \\ Oss-Emer Soares Bottega ${ }^{2}$ (D), Karine Raquel Uhdich Kleibert ${ }^{1}$ (D), Christiane de Fátima Colet $^{1}$ (D) \\ 'Departamento de Ciências da Vida, Farmácia, Universidade Regional do Noroeste do Estado do Rio Grande do Sul (UNIJUí), \\ Ijuí, RS, Brasil \\ ${ }^{2}$ Fundação Municipal de Saúde de Santa Rosa, Farmácia, Santa Rosa, RS, Brasil \\ *Corresponding author: paulalorenzoni_@outlook.com
}

\begin{abstract}
Objectives: To evaluate the profile of the drugs for continuous use prescribed in Primary Health Care (PHC) in Santa Rosa / RS and to identify presence in the official lists of essential drugs. Methods: Cross-sectional, analytical and quantitative study, with analysis of the digital prescriptions of users of primary health care in Santa Rosa. There was no gender restriction and patients who used at least one chronic drug were included. Data were collected through a printed report from users. Results: The study included 642 participants, with a mean age of $60.40 \pm 14.48,64.3 \%$ were female and $47.4 \%$, using polypharmacy. A total of 3.009 drugs were identified, with an average of $4.69 \pm 2.82$ medications/prescription. There was a higher frequency of the cardiovascular system (46.9\%), nervous system (16.8\%) and digestive tract and metabolism (14.8\%). The most commonly used drugs were hydrochlorothiazide, fluoxetine and omeprazole. Regarding the presence of drugs in the official lists, $90.9 \%$ are in RENAME and $90.8 \%$ in REMUME, and $80 \%$ of users have obtained full access to medicines. In the prescriptions, $0.3 \%$ contained antibiotics, $1.3 \%$ injectable drugs and all drugs were prescribed by the generic name and in a computerized way. Conclusions: The pharmacotherapeutic profile is similar to the national reality and most indicators are as recommended by the WHO, demonstrating the organization of the PA of the city, which facilitates the access of users to essential medicines. However, there was a high number of drugs per prescription and presence of polypharmacy, evidencing the importance of access to it as well as the promotion of the rational use of these drugs.
\end{abstract}

Keywords: Health Services Accessibility. Pharmaceutical Assistance. Quality Indicators in Health Care. Continuous Use Medications. Essential Medicines.

\section{How to cite}

Nunes PL, Bandeira VAC, Flores VB, Bottega AOES, Kleibert KRU, Colet CF. Profile of continuous use drugs prescribed in primary health care and presence in list of essential drugs. Rev Ciênc Farm Básica Apl. 2021;42:e725. https://doi.org/10.4322/2179-443X.0725 


\section{INTRODUCTION}

Public consumption and expenses on medicines are increasing and represent the second largest item of expenditure of the health care system, surpassed only by hospital care 1 . In Brazil, there was an increase of 30\% between 2010 and 2016 on investments in Pharmaceutical Assistance (PA) in the Unified Health System (UHS) ${ }^{2}$. The increase in PA funding aims to ensure the population's access to essential medicines, having as guiding instruments of the management process and pharmaceutical policies the National List of Essential Medicines (RENAME), the State List of Essential Medicines (RESME) and the Municipal List of Essential Medicines (REMUME) ${ }^{3}$.

Adequate access to drug therapy is associated with more effective control of acute and chronic non-communicable diseases, which allows reducing morbidity and mortality and improving the user's quality of life ${ }^{4}$. In Brazil $50.7 \%$ of the general population use medications ${ }^{5}$ and this percentage rises to $80 \%$ among patients with chronic diseases ${ }^{6}$. Some of the most used classes of medications are: cardiovascular system, alimentary tract and metabolism, and nervous system ${ }^{7,8}$.

As a way to evaluate the organization of PA and health services, criteria were established, based on the evaluation of prescriptions by the World Health Organization (WHO), called prescription indicators, which seek to describe and evaluate safely the aspects that affect pharmaceutical practice according to the type of problem that seems most important and according to the care services in question 9 . A study showed that more than $70 \%$ of the drugs were prescribed by the generic name, besides being present in RENAME and/or REMUME. On the other hand, some prescriptions were not in accordance with the criteria established by the WHO, with an average of more than 2 drugs per prescription and lack of information on dosage, route of administration and treatment time ${ }^{10,11}$.

Based on the aforementioned considerations, which demonstrate high consumption of medicines in the Brazilian population and prescriptions in disagreement with the criteria established by the WHO, the present study helps to know the pharmacotherapeutic profile in order to facilitate the management of health services, since the city of study is part of the full management of the health system, has a prescription system and medical records in basic care computerized and standardized for prescription by the common name.

In view of the above, the objective of this study was to evaluate the profile of the drugs for continuous use prescribed in Primary Health Care (PHC) in Santa Rosa / RS and to identify presence in the official lists of essential drugs.

\section{METHODS}

The city has been part of the full management of the health system since 1995 and has its PHC health services organized in 17 Family Health Strategies (FHS), and, since 2015, the prescription of medicines occurs electronically by the computerized system from which the participants of the present study were selected. Users registered in the 17 FHS and using at least one continuous medication were included and those who were underage were excluded. Continuous use drugs were those used for the treatment of chronic and/or degenerative diseases, used continuously ${ }^{12}$.

Data collection was performed in February and March 2017 and data were collected through analysis of the prescriptions issued in the electronic system of the city of users registered as active in January 2017, by only one pharmacy student previously trained. Information on gender, age, health unit, number of drugs prescribed, active ingredient, drug dose and posology were acquired. The use of five or more drugs was considered polypharmacy ${ }^{13}$. The drugs present in the prescriptions were classified in the first level of the Anatomical Therapeutic Chemical (ATC) classification system of the Nordic Council on Medicines, index $2020^{14}$.

The prescription according to the official lists was evaluated using: the $3^{\text {rd }}$ Edition of the Municipal List of Essential Medicines of Santa Rosa/RS - REMUME 2015/201615; list of 
medicines present in Ordinance/SES/RS n. 670/2010 and Ordinance GM/MS n. 1554/2013; $9^{\text {th }}$ edition of RENAME $/ 2014^{16}$. Although there are more current lists, those referring to the year in which the data were collected were chosen for use.

To evaluate the prescription indicators, the criteria established by the WHO were used and include: average of medications per prescription; percentage of drugs prescribed by the generic name; percentage of prescribed drugs from the list of essential medicines; percentage of prescriptions with antibiotics and percentage of prescriptions with injectable drugs ${ }^{9}$. Furthermore, information was evaluated regarding the presence of: route of administration, pharmaceutical form, treatment time and posology, and the lack of one of these observations in the prescription was considered as a problem in the prescription.

The sample was obtained using a stratified random sampling technique, with consecutive inclusion by draw, proportional to the FHS. For the constitution of the study population, the data provided by the computerized system in November 2015 were used as the basis, which contains 11.844 continuous drug users' records. For the sample calculation, a $99 \%$ confidence index and a tolerable sampling error of $4 \%$ were used, totaling 642 participants.

The data obtained were compiled into tables using the Statistical Package for the Social Sciences (SPSS) software (version 18.0). Descriptive statistics tools were used, such as measures of central tendency, dispersion and variability. For statistical analysis, the Anova test was used to verify the associated between total, partial or no access to medications with the number of prescribed medications.

All stages of the research respected the ethical precepts, and the project was approved by the Research Ethics Committee under the registration 1.428.831/2016.

\section{RESULTS}

The study included 642 drug users, with a mean age of $60.40 \pm 14.48$ years and most of the patients were women (64.3\%). The mean number of medications in use was $4.69 \pm 2.82$ medications/prescription, minimum of one and maximum of 16 . Polypharmacy was observed in $304(47.4 \%)$ of the prescriptions.

The number of drugs identified was 3,009, with a higher frequency of those acting on the cardiovascular system (46.9\%), with hydrochlorothiazide as the main medication (36.13\%), followed by the nervous system (16.8\%) with fluoxetine $(2.9 \%)$ and alimentary tract $(14.8 \%)$ with omeprazole (6.6\%), as shown in Table 1.

Table 1 - Distribution of therapeutic categories (Anatomical Therapeutic Chemical) of the medications dispensed for PHC users in Santa Rosa, RS, 2016. ( $N=3009)$

\begin{tabular}{ccc}
\hline ATC $\mathbf{1}^{\text {st }}$ Level & ATC $\mathbf{5}^{\text {th }}$ Level & $\mathbf{n}(\mathbf{\%})$ \\
\hline & Omeprazole & $200(6.64)$ \\
A - Digestive system and & Metformin & $106(3.52)$ \\
metabolism & Glibenclamide & $46(1.52)$ \\
& Calcium carbonate & $25(0.83)$ \\
& NPH Insulin & $24(0.79)$ \\
B - Blood and hematopoietic & Others & $11(0.36)$ \\
organs & Subtotal & $35(1.16)$ \\
& ASA & $\mathbf{4 4 7 ( 1 4 . 8 2 )}$ \\
& Clopidogrel & $221(7.34)$ \\
& Others & $19(0.63)$ \\
& Subtotal & $22(0.73)$ \\
\hline
\end{tabular}




\begin{tabular}{|c|c|c|}
\hline ATC $1^{\text {st }}$ Level & ATC $5^{\text {th }}$ Level & n (\%) \\
\hline \multirow{23}{*}{ C - Cardiovascular system } & Hydrochlorothiazide & $232(7.71)$ \\
\hline & Enalapril & $208(6.91)$ \\
\hline & Simvastatin & $191(6.34)$ \\
\hline & Losartan & $161(5.35)$ \\
\hline & Atenolol & $118(3.92)$ \\
\hline & Furosemide & $70(2.32)$ \\
\hline & Amlodipine & $67(2.22)$ \\
\hline & Metoprolol & $53(1.76)$ \\
\hline & Spironolactone & $49(1.62)$ \\
\hline & Propranolol & $35(1.16)$ \\
\hline & Isosorbide mononitrate & $31(1.03)$ \\
\hline & Amiodarone & $26(0.86)$ \\
\hline & Propatylnitrate & $16(0.53)$ \\
\hline & Amiloride + hydrochlorothiazide & $15(0.49)$ \\
\hline & Carvedilol & $15(0.49)$ \\
\hline & Digoxin & $15(0.49)$ \\
\hline & Ciprofibrate & $14(0.46)$ \\
\hline & Hydralazine & $13(0.43)$ \\
\hline & Verapamil & $13(0.43)$ \\
\hline & Isosorbide dinitrate & $12(0.39)$ \\
\hline & Captopril & $11(0.36)$ \\
\hline & Others & $47(1.56)$ \\
\hline & Subtotal & $1412(46.83)$ \\
\hline \multirow{4}{*}{ D - Dermatological System } & Dexamethasone & $2(0.06)$ \\
\hline & Brimonidine & $1(0.03)$ \\
\hline & Clobetasol & $1(0.03)$ \\
\hline & Subtotal & $4(0.12)$ \\
\hline \multirow{5}{*}{ G - Genitourinary System } & Levonorgestrel + ethinylestradiol & $11(0.36)$ \\
\hline & Finasteride & $9(0.29)$ \\
\hline & Isoflavones & $9(0.29)$ \\
\hline & Others & $10(0.33)$ \\
\hline & Subtotal & 39 (1.27) \\
\hline \multirow{3}{*}{ H - Hormonal System } & Levothyroxine & $84(2.79)$ \\
\hline & Others & $9(0.29)$ \\
\hline & Subtotal & $93(3.08)$ \\
\hline \multirow{4}{*}{ J - General anti-infective drugs } & Acyclovir & $2(0.06)$ \\
\hline & Collagenase+Chloramphenicol & $2(0.06)$ \\
\hline & Nitrofurantoin & $1(0.03)$ \\
\hline & Subtotal & $5(0.15)$ \\
\hline \multirow{5}{*}{$\begin{array}{l}\text { L - Antineoplastic and } \\
\text { immunomodulating agents }\end{array}$} & Methotrexate & $2(0.06)$ \\
\hline & Azathioprine & $1(0.03)$ \\
\hline & Leflunomide & $1(0.03)$ \\
\hline & Thalidomide & $1(0.03)$ \\
\hline & Subtotal & $5(0.18)$ \\
\hline \multirow{6}{*}{ M - Skeletal Muscle System } & Alendronate & $32(1.06)$ \\
\hline & Allopurinol & $24(0.79)$ \\
\hline & Ibuprofen & $11(0.36)$ \\
\hline & Cyclobenzaprine & $10(0.33)$ \\
\hline & Others & $18(0.59)$ \\
\hline & Subtotal & 95 (3.13) \\
\hline
\end{tabular}




\begin{tabular}{|c|c|c|}
\hline ATC $1^{\text {st }}$ Level & ATC $5^{\text {th }}$ Level & n (\%) \\
\hline \multirow{16}{*}{$\mathrm{N}$ - Nervous system } & Fluoxetine & $88(2.92)$ \\
\hline & Amitriptyline & $67(2.22)$ \\
\hline & Diazepam & $37(1.22)$ \\
\hline & Clonazepam & $27(0.89)$ \\
\hline & Paracetamol + codeine & $27(0.89)$ \\
\hline & Imipramine & $20(0.66)$ \\
\hline & Carbamazepine & $17(0.56)$ \\
\hline & Biperiden & $16(0.53)$ \\
\hline & Valproic acid & $13(0.43)$ \\
\hline & Haloperidol & $13(0.43)$ \\
\hline & Cinnarizine & $12(0.39)$ \\
\hline & Sertraline & $12(0.39)$ \\
\hline & Levomepromazine & $11(0.36)$ \\
\hline & Paracetamol & $11(0.36)$ \\
\hline & Others & $134(4.45)$ \\
\hline & Subtotal & $505(16.70)$ \\
\hline \multirow{6}{*}{ R - Respiratory System } & Salbutamol & $43(1.42)$ \\
\hline & Beclomethasone & $34(1.12)$ \\
\hline & Ipratropium & $19(0.63)$ \\
\hline & Formoterol & $14(0.46)$ \\
\hline & Others & $24(0.79)$ \\
\hline & Subtotal & $134(4.42)$ \\
\hline \multirow{3}{*}{ S - Sense organs } & Sodium chloride & $5(0.16)$ \\
\hline & Timolol & $3(0.09)$ \\
\hline & Subtotal & $8(0.025)$ \\
\hline
\end{tabular}

Regarding the presence of medicines in the official lists, most of them are in RENAME (90.9\%), of these 2.634 (96.2\%) of the basic component, 97 (3.6\%) of the specialized and $8(0.2 \%)$ of the strategic. Concerning the presence in REMUME, $2,735(90.8 \%)$ prescribed medicines were present.

Among the 247 drugs not present in the official UHS lists, $127(51.4 \%)$ act on the Nervous System, $52(21.1 \%)$ on the Cardiovascular System and 25 (10.1\%) on the Musculoskeletal System. Table 2 shows the relationship between the ATC classification and the components of pharmaceutical assistance.

When analyzing the prescriptions per user, $466(72.6 \%)$ had all prescribed medicines present in REMUME, 172 (26.8\%) partial access and four (0.6\%) without access. When including RENAME and special component/RS drugs in the analysis, there was full access for $531(82.7 \%)$ of the participants, 109 (17\%) partial access and two (0.3\%) without access. Access was associated with the number of drugs in use; the higher the number of drugs prescribed, the lower the access $(p<0.001)$.

Other data verified were that only two $(0.3 \%)$ prescriptions contained antibiotics and all drugs were prescribed by the generic name.

The main route of administration of the drugs was oral (94.2\%), followed by inhaled (4.1\%), injectable (1.3\%), topical (0.2\%), ophthalmic (0.1\%) and transdermal $(0.1 \%)$.

In the prescriptions analyzed, 275 (42.8\%) lack at least one of the items: route of administration, pharmaceutical form, treatment time or posology. 
Table 2 - Relationship between the main target systems of the drugs and the pharmaceutical assistance component to which they belong in the PHC in Santa Rosa, RS, 2016.

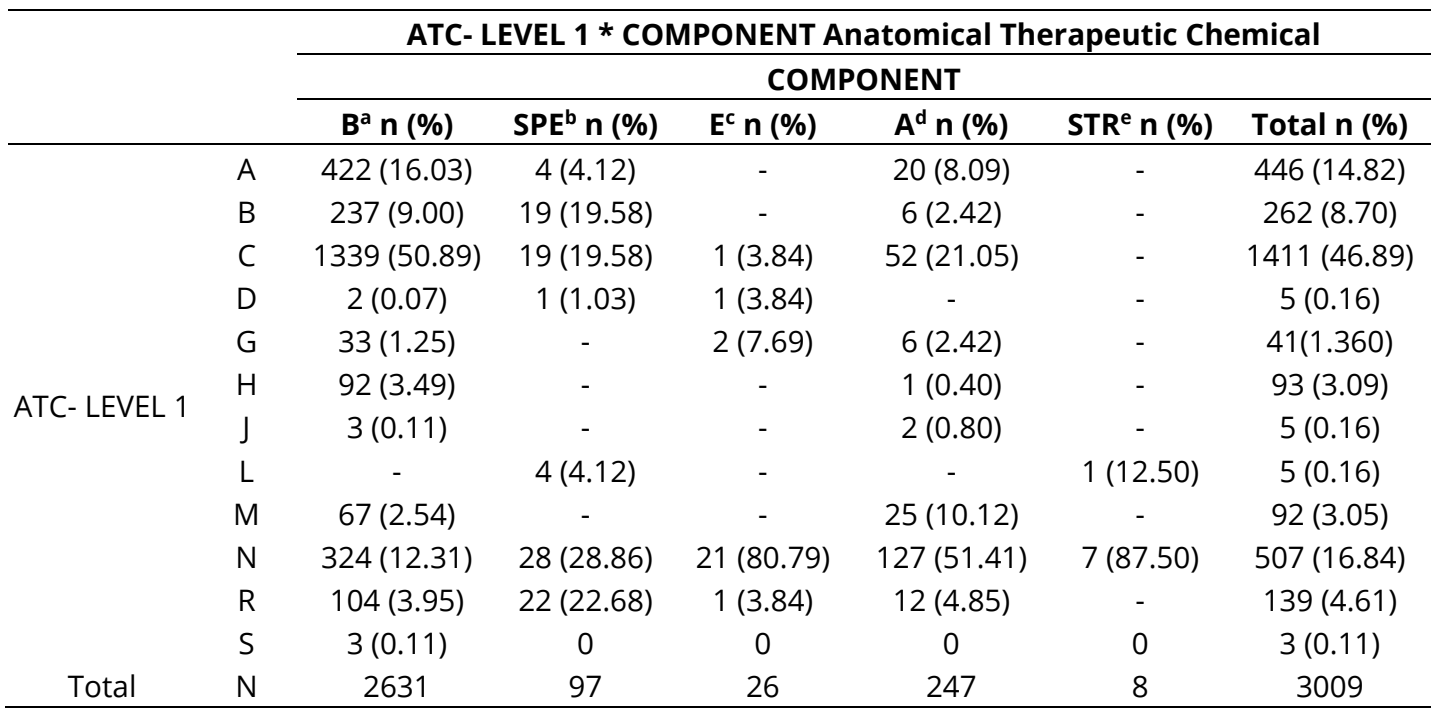

Legend: a - basic; $b$ - specialized; c - special; $d$ - absent; e - strategic

\section{DISCUSSION}

In the surveyed city, most patients have access to continuous medications, since more than $90 \%$ of the prescribed drugs are present in REMUME. This datum demonstrates that the prescribers of the city adhere to the official list of medicines ${ }^{17}$. The result was similar to those verified by Mortari et al. ${ }^{18}$, and Bandeira et al. ${ }^{10}$. The presence in the essential lists indicates a high level of organization of the municipal unified health system ${ }^{10,18}$. Furthermore, it is noteworthy that, in the city of study, PHC professionals participate annually in the REMUME update, by sending a request for the inclusion of medicines, with clinical justification to the Pharmacy and Therapeutic Commission of the city.

When analyzing the other lists of official drugs, $3.6 \%$ of the drugs are part of the specialized component and $0.2 \%$, of the strategic component, present in the RENAME. Both components aim to expand and ensure therapeutic attention for some clinical situations, especially chronic diseases, with higher treatment costs or greater complexity, regarding the specialized component ${ }^{19}$.

In the surveyed city, the pharmaceutical professional is one of the members of the Pharmacy and Therapeutics Commission (PTC), composed of a multidisciplinary team chaired by the pharmacist, and, according to Berbigier et al. ${ }^{20}$. The performance of the pharmaceutical professional with this team is important, because he/she is able to establish adequate communication between professionals ${ }^{10}$, a fact that may be responsible for most of the prescribed drugs being present in the official lists.

Concerning the prescription indicators, the average of prescribed drugs is higher than that recommended by the WHO, recommended as two medications/prescription ${ }^{9}$. The average of almost five drugs per prescription is due to the analysis including prescriptions of continuous use drugs, similar to national studies ${ }^{8,20}$. In general, prescription indicators are applied in prescriptions dispensed in health units, including both continuous and acute treatments, in the present study, only users registered with continuous use medications were analyzed, and prescriptions for specific treatments are issued separately.

The presence of polypharmacy may be related to population aging. In the current study was $47.4 \%$, higher than that observed in national studies, with frequencies between $10.30 \%$ and $37 \%$ performed in the elderly population ${ }^{7,20}$, the characteristic of a polymedicated population is associated with advanced age of the population studied, with an average of $60.40 \pm 14.48$ years. However, it corroborates the data of Silveira et al. ${ }^{13}$. The presence of 
polypharmacy is associated with negative health outcomes, such as adverse drug events, falls, fractures, hospitalizations, increased length of hospital stay, readmission to the hospital soon after discharge, as well as increased risk of mortality ${ }^{21}$.

In relation to the indicator on drugs prescribed by the generic name, the study was $100 \%$, an ideal result according to the $\mathrm{WHO}^{9}$ and higher than that found in other studies conducted in $\mathrm{Brazil}^{22,23}$. It is important to highlight that the result obtained is due to the computerized program used at the research site, since only drugs by generic name are registered, characterizing a positive point.

The number of antibiotics prescribed in the current study $(0.3 \%)$ complied with the recommended value of less than $30 \%{ }^{9}$. Thus, when comparing to other studies, the value was below those found by Stefano et al. ${ }^{8}, 21.4 \%$ and Berbigier et al. ${ }^{20}, 12.13 \%$. The indicator regarding the prescription of injectable drugs, recommending prescription percentages below $20 \%{ }^{9}$, like in present study reached. It is noteworthy that, in the present study, only prescriptions for continuous use were analyzed, and antibiotics, in general, are used in the treatment of acute health conditions, with a specific treatment period and because it is performed in a PHC, it has a lower flow injectable prescription, which are prescribed more frequently for the treatment of acute health conditions, such as in emergency and hospital services.

Another relevant factor studied is the type of writing used in the prescription. It is also noteworthy that most prescriptions are performed manually in health services, which can lead to characteristics of illegibility or lack of items that conflict with what is recommended by the legislation in force $5.991 / 73^{24}$. The current study had all prescriptions made electronically due to the computerized system, which reduces the risk of errors, a positive characteristic that guarantees the readability and integrity of the prescription fields. Total computerization is still scarce as presented in the articles by Zanetti et al. ${ }^{25}$, and Santos et al. ${ }^{26}$, who obtained only $53 \%$ and $29.8 \%$, respectively. In this study, despite the electronic prescription, an important number of prescriptions was observed with a lack of information necessary for the correct use of medications, as well as other studies in the literature ${ }^{27,28}$. The risks of lack of information can be minimized with the education of the prescribers or with a computerized system that prevents omitted information, names of incomplete medicines, medicines, with instructions to be taken when necessary without specific indication and inappropriate abbreviations ${ }^{28}$.

Regarding sociodemographic characteristics, there was a predominance of those with older age and females, as verified in other studies published in the literature ${ }^{7,8,20}$. These factors may also be related to the prevalence of the use of medications and groups corroborating other studies that bring the same groups, although with different percentages $^{7,8,20,29}$.

The predominance of medication use for the cardiovascular system, according to the Brazilian Hypertension Guideline, is associated with the advanced age of the population studied and the predominance of females ${ }^{30}$. In Brazil, the main chronic non-communicable diseases (CNCD) are those that affect the cardiovascular system, responsible for $28 \%$ of deaths in $2016^{31}$. Among the drugs of this class, the most prescribed was hydrochlorothiazide $(36.13 \%)$, a datum similar to that found in studies conducted by Almeida et al. ${ }^{7}$, Silva ${ }^{32}$ and more recently, Andrade et al. ${ }^{29}$.

The most prescribed pharmacological class of the nervous system was antidepressant. In 2015 , depression reached about $5.8 \%$ of the Brazilian population, above the global percentage (4.4\%) of the same year ${ }^{33}$. The most common antidepressant medicine was fluoxetine (2\%) similar to that found by Andrade et al. ${ }^{29}$. A study conducted nationally showed that $38.8 \%$ of the drugs prescribed belonged to the class of antidepressants, highlighting fluoxetine $(28.8 \%)^{34}$. Also, according to the authors, the Southern region had the highest prevalence of fluoxetine use among all regions (5.0\%). Fluoxetine belongs to the list of inappropriate medications for the elderly (IPM) as it can produce ataxia, compromise psychomotor function, syncope and additional falls, resulting in a negative outcome for the patient ${ }^{35}$. 
Finally, it was possible to verify the high consumption of medicines for the digestive tract and metabolism. Antiulcer drugs are often used among the elderly and those performed by other authors ${ }^{7,20,29}$. The use of this medication is safe when used as indicated, however, prolonged treatment may promote loss of gastric acidity, which may decrease the absorption of vitamin B12, as well as affect the bioavailability of some drugs ${ }^{36}$. Like fluoxetine or omeprazole, which is on the list of IPM, bringing the risk of developing osteoporosis / fracture, dementia and renal failure with prolonged use $\mathrm{e}^{35}$.

The medicines for metabolism most present in the research were oral antidiabetics. In the present study, metformin (3.5) stood out, corroborating Almeida et al. ${ }^{7}$, and Andrade et al. ${ }^{29}$. This drug, according to the Brazilian Diabetes Society (SBD) ${ }^{37}$, is part of the first-line treatment, being considered the drug of choice for treatment.

The study revealed the importance of building the lists considering the scientific evidence regarding efficacy, effectiveness, safety, cost, availability ${ }^{19}$ and the pharmacotherapeutic profile. One limitation faced in the research was the fact that the system prescriptions were evaluated and not the availability of medications in the FHS. It is also noteworthy that the city is responsible for ensuring that the drugs on the lists are available to the population and carrying out guidance for rational use.

\section{CONCLUSION}

The pharmacotherapeutic profile is similar to the national reality, whose most prescribed medications act on the cardiovascular system. The prescriptions analyzed showed that the indicators aimed at ensuring access, such as presence in official lists and prescription by generic name, complied with the WHO recommendation, indicating the high organization of PA in the city, as well as the proportion of antibiotics and injectable drugs. However, the average number of drugs per prescription was higher than established, highlighting the prevalence of polypharmacy. As for the readability of the prescriptions, their total computerization ensures the correct interpretation, avoiding possible errors derived from doubts.

Nevertheless, a high number of drugs per prescription and presence of polypharmacy was evidenced, unveiling the importance of access as well as the promotion of rational use of these drugs.

\section{REFERENCES}

1. Nery AAP. Assisstencia networks in pharmaceutical health care health System in Single - SUS Journal of Biology \& Pharmacy and Agricultural Management - BIOFARM [Internet]. 2014 [cited 2020 Jun 24];10(3):20-30. Available from:

http://revista.uepb.edu.br/index.php/biofarm/article/view/2239

2. Vieira FS. Evolução do gasto com medicamentos do Sistema Único de Saúde no período de 2010 a 2016. Rio de Janeiro; IPEA; 2018. Texto para Discussão.

3. Conselho Federal de Farmácia. O farmacêutico na assistência farmacêutica do SUS: diretrizes para ação. Brasília, DF: CFF; 2015.

4. Gontijo MF, Ribeiro AQ, Klein CH, Rozenfeld S, Acurcio FA. Uso de anti-hipertensivos e antidiabéticos por idosos: inquérito em Belo Horizonte, Minas Gerais, Brasil. Cad Saude Publica. 2012;28(7):1337-46. http://dx.doi.org/10.1590/S0102-311X2012000700012. PMid:22729264.

5. Bertoldi $A D$, et al. Perfil sociodemográfico dos usuários de medicamentos no Brasil: resultados da PNAUM 2014. Rev Saúde Pública. [Internet]. 2016 [cited 2019 Dec 18];50(supl 2):5s. Available from: http://www.scielo.br/scielo.php?script=sci_abstract\&pid=S0034$89102016000300310 \&$ Ing=en\&nrm=iso\&tlng=pt

6. Tavares NUL, Costa KS, Mengue SS, Vieira MLFP, Malta DC, Silva JB Jr. Uso de medicamentos para tratamento de doenças crônicas não transmissíveis no Brasil: resultados da Pesquisa Nacional de Saúde, 2013. Epidemiol Serv Saude. 2015;24(2):315-23. http://dx.doi.org/10.5123/S167949742015000200014. 
7. Almeida NA, Reiners AAO, Azevedo RCS, Silva AMC, Cardoso JDC, Souza LC. Prevalence of and factors associated with polypharmacy among elderly persons resident in the community. Rev Bras Geriatr Gerontol. 2017;20(1):138-48. http://dx.doi.org/10.1590/1981-22562017020.160086.

8. Stefano ICA, Conterno LO, Silva CR Fo, Marin MJS, Stefano ICA, Conterno LO, Silva CR Fo, Marin MJS. Medication use by the elderly: analysis of prescribing, dispensing, and use in a medium-sized city in the state of São Paulo. Rev Bras Geriatr Gerontol. 2017;20(5):679-90. http://dx.doi.org/10.1590/1981-22562017020.170062.

9. World Health Organization. Prescribing. In: World Health Organization. Guide to drug financing mechanisms. Geneva: WHO; 1998.

10. Bandeira VAC, Hermann CTS, Siqueira CM, Oliveira KR. Análise das prescrições dispensadas em uma unidade básica de saúde do município de ljuí - RS. Saúde (Sta Maria). 2015;41(1):229-38.

11. Guttier MC, Silveira MPT, Gouvea DS, Fonseca AS, Cognato GP, Silva JFM. Avaliação de indicadores de prescrição e conhecimento dos usuários sobre medicamentos prescritos em duas unidades de saúde de Pelotas-RS. BJHR. 2019;2(6):5741-60. http://dx.doi.org/10.34119/bjhrv2n6-069.

12. Brasil. Ministério da Saúde. Portaria n 3.916, de 30 de outubro de 1998. Diário Oficial da União [Internet]; Brasília; 1998 [cited 2020 Jan 16]. Available from: https://bvsms.saude.gov.br/bvs/saudelegis/gm/1998/prt3916_30_10_1998.html

13. Silveira PA, Silva SC, Rocha KSC. Prevalência da polifarmácia nos idosos de uma Unidade Básica de Saúde no estado de Minas Gerais. Rev Atenção Saúde. [Internet]. 2019 Apr 15 [cited 2020 Jan 16];16(58):29-35. Available from: http://seer.uscs.edu.br/index.php/revista_ciencias_saude/article/view/5364

14. World Health Organization. Anatomical Therapeutic Chemical Classification - ATC/DDD Index2020 [Internet]. WHO Collaborating Centre for Drug Statistics Methodology; 2020 [cited 2020 May 29]. Available from: www.whocc.no/atc_ddd_index/

15. Fundação Municipal de Saúde - Santa Rosa. Relação Municipal de Medicamentos Essenciais: REMUME. Santa Rosa, RS: FUMSSAR; 2015.

16. Brasil. Ministério da Saúde. Relação Nacional de Medicamentos Essenciais: RENAME 2014. Brasília, DF: MS; 2015.

17. World Health Organization. Access to Essential Medicines. The World Medicines Situation. Geneva: WHO; 2004.

18. Mortari C, Henn RL, Paniz VMV. Avaliação dos indicadores de prescrição e dispensação de medicamentos no município de Feliz/RS. Rev Bras Farm. 2014;95(3):833-54.

19. Brasil. Ministério da Saúde. Relação Nacional de Medicamentos Essenciais: RENAME 2020. Brasília, DF: MS; 2019.

20. Berbigier I, Bielefeld LA, Wazenkeski ES, Brandalise M, Santos L, de Souza AH. Análise em prescrições para idosos na farmácia municipal de Esteio - RS: Avaliação de impactos e proposta de intervenção farmacêutica com terapêutica mais segura para a população idosa. Rev Iniciaç Cient ULBRA [Internet]. 2017 [cited 2020 Jan 7];1(15):17-27. Available from: http://www.periodicos.ulbra.br/index.php/ic/article/view/3452

21. Masnoon N, Shakib S, Kalisch-Ellett L, Caughey GE. What is polypharmacy? A systematic review of definitions. BMC Geriatr. 2017;17(1):230. http://dx.doi.org/10.1186/s12877-017-0621-2. PMid:29017448.

22. Mohr CNA. Análise de receitas de medicamentos dispensados em uma farmácia regional do SUS no município de Sinop no ano de 2015 [Internet] [Trabalho de Conclusão de Curso]. Sinop, MT: Universidade Federal de Mato Grosso; 2018 [cited 2020 May 29]. Available from: http://bdm.ufmt.br/bitstream/1/1394/1/TCC-2018CHARLES\%20NATAN\%20DE\%20ASSIS\%20MOHR.pdf

23. Silva FRR. Indicadores de qualidade em prescrições medicamentosas [Trabalho de Conclusão de Curso]. Juiz de Fora, MG: Universidade Federal de Juiz de Fora; 2016.

24. Brasil. Lei $n^{\circ}$ 5.991, de 17 de dezembro de 1973. Dispõe sobre o Controle Sanitário do Comércio de Drogas, Medicamentos, Insumos Farmacêuticos e Correlatos, e dá outras Providências. Diário Oficial da União [Internet]; Brasília; 1973 [cited 2020 May 29]. Available from: http://www.planalto.gov.br/ccivil_03/leis/15991.htm 
25. Zanetti MO, Marchetti JM, Andrade RCG. Adequação da prescrição de medicamentos na Atenção Primária à Saúde de Ribeirão Preto-SP: estudo transversal. Rev Bras Med Fam Comunidade. 2018;12(39):1-11. http://dx.doi.org/10.5712/rbmfc12(39)1443.

26. Santos PRA, Rocha FLR, Sampaio CSJC. Ações para segurança na prescrição, uso e administração de medicamentos em unidades de pronto atendimento. Rev Gaúcha Enferm. 2019;40(spe):e20180347. http://dx.doi.org/10.1590/1983-1447.2019.20180347.

27. Devine EB, Hansen RN, Wilson-Norton JL, Lawless NM, Fisk AW, Blough DK, Martin DP, Sullivan SD. The impact of computerized provider order entry on medication errors in a multispecialty group practice. J Am Med Inform Assoc. 2010;17(1):78-84. http://dx.doi.org/10.1197/jamia.M3285. PMid:20064806.

28. Nanji KC, Rothschild JM, Salzberg C, Keohane CA, Zigmont K, Devita J, Gandhi TK, Dalal AK, Bates DW, Poon EG. Errors associated with outpatient computerized prescribing systems. J Am Med Inform Assoc. 2011;18(6):767-73. http://dx.doi.org/10.1136/amiajnl-2011-000205. PMid:21715428.

29. Andrade CP, Engroff P, Sgnaolin V, Gomes I, Terra NL. Perfil do uso de medicamentos por idosos da Estratégia Saúde da Família de Porto Alegre. Saúde (Sta Maria). 2019;45(2):1-13. http://dx.doi.org/10.5902/2236583438238.

30. Malachias M, editor. $7^{a}$ Diretriz Brasileira de Hipertensão Arterial. Arq Bras Cardiol. [Internet]. 2016 [cited 2020 Jun 13];107(3):195-285. Available from: http://www.gnresearch.org/doi/10.5935/abc.20160151.

31. World Health Organization. Noncommunicable Diseases (NCD) Country Profiles 2018. Geneva: WHO; 2018.

32. Silva AS. Assistência Farmacêutica na Atenção Básica à Saúde: avaliação de indicadores de racionalidade do uso de medicamentos. Recife, PE: Universidade Federal de Pernambuco; 2017.

33. World Health Organization. Depression and Other Common Mental Disorders: Global Health Estimates. Geneva: WHO; 2017.

34. Machado AV. O uso de fluoxetina e fatores associados : estudo populacional [Internet] [dissertação]. Brasília: Universidade de Brasília; 2018 [cited 2020 Jul 16]. Available from: https://repositorio.unb.br/handle/10482/32076

35. American Geriatrics Society. American Geriatrics Society 2019 Updated AGS Beers Criteria® for potentially inappropriate medication use in older adults. J Am Geriatr Soc. 2019;67(4):674-94. http://dx.doi.org/10.1111/jgs.15767. PMid:30693946.

36. Lorenz C, Schneider A, Oliveira KR, Colet CDF. Perfil sociodemográfico e clínico de idosos usuários crônicos de omeprazol na rede básica de saúde. R Pesq Cuid Fundam online. 2019;11(4):900-7.

37. Sociedade Brasileira de Diabetes. Diretriz Sociedade Brasileira de Diabetes 2019-2020. Rio de Janeiro: Sociedade Brasileira de Diabetes; 2019.

\section{Authors' contributions}

PLN: Data curation, Investigation, Methodology, Writing - original draft; VADCB: Conceptualization, Investigation, Methodology, Writing - review \& editing; VBF: Conceptualization, Data curation, Methodology; AOSB: Conceptualization, Data curation, Methodology; KRUK: Data curation, Writing - review \& editing; CFC: Conceptualization, Writing - review \& editing. 